\title{
A APROPRIAÇÃO ECOLÓGICA DE SERINGAIS NA AMAZÔNIA E A ADVOCACIA DAS RUBBER PLANTATIONS *
}

\begin{abstract}
Rosineide Bentes
Museu Emílio Goeldi

\section{Resumo}

Visões conflitantes de meio ambiente e propriedade marcaram a história da apropriação dos seringais de 1840 até às primeiras décadas do séc. XX. A apropriação ecológica local - na qual terra significava floresta e o número economicamente lucrativo de seringueiras definia o tamanho e os contornos da propriedade seringueira - colidiu com o sentido científico-territorial da terra: apenas um solo a ser desmatado para a monocultura, sendo a propriedade definida por sua extensão. Os promotores das plantations associaram-nas a civilidade e os seringais a incivilidade e primitivismo, ofuscando a complexa combinação de percepção ecológica da natureza com concepções modernas de propriedade e de terra que caracterizava os seringais.

\section{Pallavras-Chave}

Amazônia • Ecologia • Terra • Borracha $\bullet$ Tecnologia

\section{Abstract}

Conflicting understandings of environment and property marked the history of rubber production in the Brazilian Amazon from 1840 to the early twentieth century. The local ecological approach to tenure - in which land was defined by the total forest ecology, and where the size and contours of property were delimited by the number of rubber trees that could be tapped profitably clashed with the scientific-territorial meaning of land: a soil to be mastered through monoculture, with property defined by its territorial extension. The proponents of rubber plantations associated these properties to civility and progress, while associating the rubber-tapping economy to a lack of civilization and to primitivism, thus obfuscating the complex combination of ecological perceptions of the environment and modern notions of property and land tenure, which characterized the rubber extraction areas.
\end{abstract}

\section{Keywords}

The Amazon • Ecology • Land Tenure • Technology

\footnotetext{
*Artigo baseado no cap. 2 da tese de doutorado (Bentes, 1998), em pesquisa complementar para livro em preparação e artigo apresentado na 2001 Conference of Environmental History and History Societies, em Durham, North Carolina. Agradeço os comentários de William Balée, Elinor Melville, Linda Lewin e Thomas Holloway. O tema é objeto da pesquisa "Tecnologia Moderna e Natureza: O Simbolismo da Amazônia para o Império Britânico nos anos 1900-15 e as Políticas do Governo Federal para a Região". Bolsa CNPq, DCR, Museu Emílio Goeldi.
} 
A história dos seringais e da Amazônia através de noções de primitivismo e nomadismo ignora o significado ecológico de terra que norteou a apropriação dos seringais e a rejeição dos seringalistas à advocacia das rubber plantations pelo governo e pelos britânicos. ${ }^{1}$ Inspirada na mesma perspectiva evolucionista que guiou a promoção das plantations, segundo a qual floresta preservada significaria primitivismo e incivilidade, essa história descreve a Amazônia como floresta bruta, objeto de extração circunstancial de recursos naturais, um território vazio e primitivo à margem do Brasil civilizado. ${ }^{2} \mathrm{Fa}-$ brica-se o pioneirismo do imigrante recente e a invisibilidade dos amazônidas e povos indígenas (Bentes 2002, 1996 e 1991). Santos (1980) demonstrou que a Amazônia não era território vazio e que tem uma história. A idéia subjacente a esse estudo e aos de Weinstein (1983) e Martinelo (1988), todavia, é de que as plantations e a industrialização representariam nível superior de evolução humana em contraste com o primitivismo dos seringais. O foco de interesse é a esfera comercial e financeira. Os seringais são avaliados pelo nível de incorporação de tecnologias modernas, e isto reflete o sentido de história adotado: a história da modernização, que atribui status superior a tudo que é considerado moderno - pessoas, conhecimento, tecnologia e valores de países e regiões industrializadas (Iggers 1977). ${ }^{3}$ A produção da borracha teria fracassado em modernizar-se e desaparecido. Martinelo questiona a tese de descontinuidade, mas segue os demais autores no trato fragmentado da propriedade da terra:

\footnotetext{
${ }^{1}$ O empresário da borracha era chamado seringalista (Soares 1927) ou seringueiro, pois o termo patrão o distinguia do trabalhador do seringal. Neste artigo seringalista, empresário, fazendeiro e capitalista referem-se a empresários capitalistas, e seringueiro ao empregado do seringal especializado na produção de borracha. O termo produtor familial é usado para diferenciar a economia familiar autônoma, baseada em mão-de-obra familiar, da empresa capitalista. Não se adota o termo caboclo (Frechione, Posey and Da Silva 1989; Parker 1985) por ainda possuir conotação racista colonial contra pessoas com descendência indígena (Fausto 1999:26; Hemming 1987:Parte 1) e, como categoria de análise, esconder tanto que a sociedade Amazônica é um tipo de sociedade capitalista estratificada quanto que a população rural, composta de empresários, trabalhadores, produtores familiares e comunidades indígenas é influenciada não apenas pelos grupos indígenas e culturas ibéricas, mas também por uma variedade de culturas trazidas por imigrantes árabes, europeus, africanos e asiáticos.

${ }^{2}$ Veja visão crítica da perspectiva evolucionista em Bentes 1998; McLeish 1991:125; Thomas 1983: 25 e 29; Drayton, 2000; Grove, 1995; Bowler, 1993; Bowler, 1989 c1983; Bowler, 1989; Bowler, 1988; Bowler, 1990.

${ }^{3}$ Pagden 1995 e Drayton 2000 mostram que reivindicar para si comando universal baseado no argumento de comunidade superior é uma tradição do Oeste Europeu.
} 
simples menção a ela ou a noção errônea de que ela teria acontecido no auge da produção-exportação de borracha e somente no alto Amazonas. $\mathrm{O}$ ambientalismo reconhece a lacuna no que diz respeito à propriedade dos seringais apenas para reformular a idéia de fracasso: o boom teria fracassado por não ter desencadeado um desenvolvimento mais balanceado e sustentável (Cooames and Barham 1994; Barham and Coomes 1996). Dean (1989) mostra a importância do meio físico, mas exagera o papel das pragas no insucesso das rubber plantations. Ao ignorar ou minimizar o papel dos amazônidas, obscurece-se a história da apropriação dos seringais.

Este artigo trata da apropriação dos seringais através da discussão sobre significados conflitantes de natureza, propriedade, ocupação e uso produtivo que marcaram os anos de 1840 até o início do século XX. A apropriação ecológica dos seringais - na qual terra significava floresta de goma elástica e o número economicamente lucrativo de seringueiras definia o tamanho e os contornos de uma propriedade - colidiu com o sentido científico-territorial de terra e propriedade da advocacia das plantations pelo Estado e pelos britânicos: apenas um solo a ser desmatado para a monocultura, sendo a propriedade definida por sua extensão. Os britânicos inventaram as rubber plantations símbolo de progresso e civilidade e os seringais, nômades e predatórios. Os interesses políticos e ideologias contemporâneas emiscuídas nessas visões tornam-se evidentes à medida que este artigo trata os amazônidas como atores históricos, considerando as vozes daqueles que questionaram o olhar científico. ${ }^{4}$ Ao contrário da ciência que separa uso produtivo de práticas de conservação, os métodos ecológicos de produção de borracha ancoravam-se na preservação da ecologia do seringal; e isto singularizou a propriedade seringueira, que no geral seguia os padrões legais e sociais do resto do Brasil: propriedade privada da terra, que era capital produtivo e mercadoria valiosa de acesso socialmente desigual. ${ }^{5}$

\footnotetext{
${ }^{4}$ O procedimento vem sendo contruído desde 1987 com base em fontes primárias (Bentes 1991, 1998 e IDESP (Bentes) 1992) e foi recentemente enriquecido com trabalhos de antropologia ambiental (Balée 1989), história ambiental (Melville1994; Cronon 1996), imperialismo verde (Grove op. cit. e Drayton op. cit.), história da ciência e sociologia do conhecimento (Palladino and Worboys 1993; Bowler 1989:14-20; Mulkay 1979; Barnes \& Shapin 1979; Shapin s/d).

${ }^{5}$ Propriedade privada significa propriedade de um ou mais indivíduos e um direito (Novo Aurélio Século XXI: Dicionário da Língua Portuguesa, 3rd. Ed., s.v. "propriedade privada"; Academic American Encyclopedia 12 ${ }^{\text {th }}$ ed.,s.v. "private property").
} 


\section{A Apropriação Ecológica da Terra}

Antes da década de 1840, empresas rurais, privadas e estatais, produtores familiares e comunidades indígenas exploravam os seringais que existiam dentro de suas terras, enquanto outros organizavam arranchamentos (empresas temporárias) para explorar seringais devolutos. Eles tinham aprendido os métodos indígenas de extração e manufatura do látex, registrados desde 1511 na Amazônia Peruana e do séc XII no Grão Pará. Através do aperfeiçoamento desses métodos, desde o início do séc XVIII produziam-se e exportavam-se, no Grão Pará, vários artigos à prova d'água. Em Belém, desde o início do séc. XIX, pequenas fábricas produziam e exportavam artigos variados para Portugal e Estados Unidos (Reis 1957:47; Drabble 1973;Coates 1987: 4-10 and 14; Cruz 1973; Santos op.cit.). A exportação da matéria-prima borracha começa somente em 1844. A produção exclusiva ou principal da borracha e a tendência ao aumento dos preços provocado pela crescente demanda internacional em especial após 1839, quando, ao tentar adaptar os métodos amazônicos à grande indústria capitalista, estrangeiros criaram a vulcanização - valorizaram a terra-seringal como capital produtivo e mercadoria valiosa, apropriada segundo os padrões ecológicos regionais. ${ }^{6}$

No vale do Amazonas, os portugueses começaram a se apropriar da terra em 1615 através de guerra contra os Tupinambás e baseados em conhecimentos indígenas sobre a diversidade e complexidade do meio físico, adquiridos através de expedições exploratórias oficiais ou particulares, relações de amizade e casamentos. ${ }^{7}$ Os nativos ocupavam conjuntos particulares de solos e rios localizados em meios naturais diversificados: a costa Atlântica, os vales dos rios e lagos, tanto no interior da floresta, como em campos e várzeas (Oliveira 1994; Balée op.cit.; Roosevelt 1994; Porro 1994). A ocupação seletiva exigia conhecimento profundo sobre o meio físico, pois, como pesquisas recentes revelam, $88 \%$ do solo Amazônico é do tipo pobre em nutrientes, enquanto $12 \%$, moderado ou extremamente fértil, representa 50 milhões de hectares, área equivalente ao total da terra dedicada à agricultura e pastoreio no resto do Brasil (Nascimento \& Homma 1984).

\footnotetext{
${ }^{6}$ Bentes 1998:196-209 discute dados disponíveis e bibliografia sobre preços.

${ }^{7}$ Grandes expedições são bem conhecidas (Medina 1934; Acunã 1698; Ferreira 1970; Fonseca 1875:203-355). Importantes para a apropriação da terra eram as pequenas expedições que precediam as ações dos governadores do Gão Pará.
} 
Para transformar esse meio físico em capital produtivo, os portugueses criaram tecnologia própria através da combinação de conhecimentos e métodos indígenas com aqueles trazidos de Portugal, onde se costumava absorver conhecimentos e técnicas de outros povos. ${ }^{8}$ Eles dependiam também do trabalho dos indígenas, e de sua transformação em súditos leais, a população portuguesa era muito pequena para povoar a Amazônia. Apesar da admiração inicial, os portugueses perceberam os povos indígenas através da noção greco-romana de bárbaros, e a partir do séc. XVIII, da noção iluminista de selvagem, povo inferior incapaz de pensamento racional (Gondim 1994). ${ }^{9}$ Eles escravizaram muitos nativos e também fizeram esforços para incorporar outros na sociedade colonial, transformando-os em aliados contra inimigos europeus. Essas estratégias implicaram a tomada paulatina da terra com a construção de fortes e fortalezas. Após a fundação de Belém, a apropriação de terras passou a ser mediada por missionários que convenciam os indígenas a deixarem suas terras e mudar-se para aldeias católicas. Aqueles que recusavam a oferta eram considerados em guerra e permitia-se a escravização de prisioneiros de guerra. ${ }^{10}$ Negociações ocorriam para legitimar as terras ou doar novas a grupos que tivessem chegado a um acordo com o governador.

Inicialmente, empresas eram organizadas nas cercanias dos fortes. Inspiradas na visão científico-territorial de terra, as empresas açucareiras praticavam o rodízio de solos e competiam com os molinotes (produtores de aguardente) pelos solos férteis. Essas empresas e os ranchos desmatavam para o cultivo de cana e de pasto. À medida que aprendiam com os nativos elas adaptavam tecnologias visando maximizar lucros. Os moinhos e molinotes descobriram as várzeas férteis onde podiam cultivar cana no mesmo pedaço de terra por até 25 anos. Os colonizadores permaneceram na foz do rio Amazonas até 1640. Em 1696 eles passaram a criar gado nas campinas naturais da Ilha do Marajó

\footnotetext{
${ }^{8}$ Relatório de expedições oficial e particular, além de vários documentos oficiais indicam a maneira como os portugueses observavam e aprendiam técnicas e conhecimentos indígenas. A exemplo do relatório de Noronha (1856). Sobre a influência de outras culturas no império português veja Arnold 2002; Russel-Wood 1998;Lapa 1966.

${ }^{9}$ Sobre o conceito de "barbárie" criado por escritores gregos e pelos Romanos veja (Davies 1999:113-114; Pagden op. cit.).

${ }^{10}$ Reis 1942 discute fortes e fortalezas e Bentes 1998:cap.3 mostra a criação de trabalhadores. Moreira Neto 1988; Hemming 1987: part 1 revelam o impacto da colonização portuguesa sobre as populacões indígenas.
} 
(Bentes 1991). A partir do séc. XVIII intensificou-se a apropriação de campinas para gado (Serrão 1986; Moura1989; Eden, McGregor and Vieira 1990) e ecossistemas variados em toda a região.

A apropriação de terra envolvia problemas e contradições. No séc. XVIII, Padre Daniel discute a degradação do solo provocada por aqueles que adaptavam os métodos de queimadas dos Tupinambás à produção em larga escala em terra firme infértil (Daniel 1976). Ele mostra a necessidade de retorno aos métodos indígenas mais tradicionais, enquanto os chama de feras e selvagens. A visão iluminista européia de superioridade e autoridade sobre os povos nativos mascara assim a dependência portuguesa dos métodos ecológicos de plantio-manejo dos índios.

De 1754 a 1777, a política pombalina visou superar o legado cultural indígena promovendo a importação de tecnologias européias, em particular inglesa, às quais atribuía status superior. Cresceu a importação de moinhos de açúcar e outras tecnologias manufatureiras, mas a monocultura no Grão Pará perdia terreno, pois aprender-recriar métodos ecológicos de plantio-manejo de florestas e campinas tinha se tornado prática comum em uma sociedade que já pensava terra como ecossistemas particulares. Repensar costumes e técnicas européias através de valores e métodos ecológicos ofendia os representantes da Coroa. Em 1758, o governo reclamava que os colonos teriam adotado métodos e costumes indígenas. A lei de 1755 que incentivava o casamento de portugueses com nativos teria fracassado porque em vez de civilizar os indígenas, os portugueses teriam absorvido seus costumes. De fato, era costume ocupar a terra seletivamente, porém, diferente dos indígenas, ao escolhê-las, investidores amazônidas e residentes consideravam sua adequabilidade à produção de determinado artigo e também o potencial de geração de lucros. As melhores terras eram aquelas que ofereciam solos férteis, florestas e campinas valiosas e/ou rios e costa marítima piscosa e acesso fácil aos mercados locais e portos de exportação. Na segunda metade do séc. XVIII, as melhores terras já haviam sido apropriadas tanto em áreas centrais como nas várzeas férteis - aquelas irrigadas anualmente pela enchente dos rios de água barrenta (Nascimento \& Homma op.cit.). ${ }^{11}$ Mudanças nos preços de produtos de expor-

\footnotetext{
${ }^{11}$ Acerca de apropriação seletiva de terra veja Bentes 1991 e Denevan 1984: 311-336; várzeas veja também Stenberg 1998 e geopolítica na apropriação de terras, Almeida 1990 e Reis 1982.
} 
tação valorizaram novas terras, exploradas de modos diversos, resultando em zonas ecológico-econômicas distintas. ${ }^{12}$ A apropriação seletiva da terra, ilustrada no Mapa 2, significou diversidade econômica.

Ao apropriar seringais, os seringalistas reproduzem a mesma percepção ecológica de natureza com a particularidade de que terra significava floresta de seringueiras. A apropriação seletiva dos seringais ocorreu simultaneamente em toda a região exigindo conhecimento profundo da ecologia. ${ }^{13} \mathrm{~A}$ densa distribuição de espécies nobres definia o grau de produtividade e valor comercial de um seringal, pois espécies diferentes resultavam em borracha de qualidades diversas, vendidas a preços diferenciados. A produtividade e qualidade do látex dependiam também da idade da árvore (tempo de exploração de 30 a 70 anos) e da topografia e qualidade do solo. O período de safra variava levemente em cada microrregião. Conhecimento e tino empresarial levaram os seringalistas a instalar extensas empresas às margens de rios navegáveis, devido à incidência de densos seringais nas várzeas, e também em áreas centrais, pois densos seringais localizavam-se em terras firmes caracterizadas por alto grau de pluviosidade, a espécie Castilloa Ulei era típica de áreas secas e a alta densidade de seringueiras compensava os altos custos de transporte. ${ }^{14}$

\section{Ecologia e Modernidade}

O significado ecológico de terra imiscuía-se em sentidos modernos de terra-seringal, capital produtivo e mercadoria valiosa, cujo acesso, seguia os padrões do resto do Brasil. Até 1850, podia-se obter terra através de doação

\footnotetext{
${ }^{12}$ Vários autores descrevem as áreas e a agricultura praticada na região (Denevan $o p$. cit.; Salles 1971; Edwards 1847:130; Wallace 1939:173; Bates 1979:102; Cordeiro 1920:16; Bastos 1938: 207).

${ }^{13}$ A apropriação seletiva contradiz a noção de expansão linear do Este para o Oeste (Quintiliano 1963; Bonfim 1954; Santos op. cit.), ou 'fronteira' (Oliveira Filho 1979).

${ }^{14}$ Mendes, 1910:334; Revista da Associação Comercial do Amazonas-ACA, Editorial Nov.908 e (Nov.1912):3; Souza 1914; Benoliel 1908; Folha do Norte 1913;IBGE 1907; Cunha 1946; Bonfin op. cit.:15 e 18; Silva 1962:71; Silva 1982; Duarte 1987:25-26; Falcão s/d; Revista da Associação Comercial do Pará (ACP), Set.Out/1927: 131; Guedes 1920:91-92; Reis 1953:80; Magalhães 1977:15-16.

${ }^{15}$ Sobre os padrões legais e sociais de apropriação de terra na Amazônia veja Bentes, 1991,Treccani 2001: cap.1-5, Emmi 1988; IDESP(Rosineide Bentes) op. cit.; Magalhães op. cit.; Duarte op. cit. Viotti da Costa 1985, Dean, 1971 e muitos outros tratam da apropriação de terras no resto do Brasil.
} 
oficial, parceria, e posse de terras devolutas. ${ }^{15}$ Ao se referir à situação legal de terras que ainda não houvessem sido privatizadas ou destinadas a uso público ou reserva indígena, ignorando a condição de ocupação ou não destas, o conceito de terras devolutas fragilizava povos nativos e o produtor familial que porventura as habitassem. A exigência de posse de capital ou crédito na praça para a doação de terras teve efeitos desastrosos numa sociedade estratificada: as classes altas e médias apropriaram-se das melhores terras, deixando as mais distantes e menos férteis para os pobres (Bentes 1991). A lei de terras legitimou seu acesso desigual ao estabelecer a compra como única forma de obter terras devolutas. Outras condições também favoreceram os empresários.

As indústrias de derivados de borracha americana e européia nasciam dependentes da pequena oferta de artigos de látex da Amazônia, única fornecedora até a década de 1860. Não havia exportação de matéria-prima. Ela foi induzida. Enquanto industriais, cientistas e outros experts estrangeiros aprendiam os métodos e técnicas locais de manufatura de derivados do látex, adaptandoos às suas indústrias sob gerenciamento científico, comerciantes e financiadores europeus ofereciam crédito fácil e barato à produção de borracha, bem como os serviços de comércio-exportação (Associação Comercial do Pará (ACP). Relatórios Anuais; F.O. and The Board of Trade 1902:4; Santos op.cit: 134-36). A exportação, que foi de 185 kilos de manufaturas de látex em 1836-37, aumentou para 381 toneladas de borracha em 1850, somente para o Reino Unido. A navegação a vapor intensificou o acesso a seringais mais distantes e a maior empresa regional, criada em 1853, foi comprada pelos ingleses em 1872 (Reis 1957:67-68; Graham 1969; Santos op.cit.). O impacto do estímulo estrangeiro deve-se também ao contexto nacional de instabilidade econômica e política.

Os principais produtos de exportação eram caracterizados por flutuação de preços e crises econômicas periódicas. Os efeitos da crise de preços do açúcar e do declínio da produção de ouro da década de 1770 foram minimizados no Sudeste pela produção do café a partir dos anos 1830 e pela volta do Rio de Janeiro como um dos maiores produtores de açúcar (Furtado 1959; Schwartz 1985:428). No Nordeste, em 1780-1830, aumentou a produção de tabaco, algodão e açúcar. Mas a crise penalizou partes do Nordeste e a Amazônia. Nesta, os efeitos da flutuação de preços somavam-se ao transporte difícil para os portos exportadores localizados no Nordeste, e ao desestímulo da política de Pombal, que priorizou a exportação açucareira nordestina. A exportação de açúcar caiu de 1.338 arrobas em 1758 para 9 arrobas em 1777. Após 1853, o aumento temporário de preços incrementou essa exportação, que chegou a 112.336 arrobas em 
1868-70; isto, porém, não preveniu o abandono gradual do açúcar em favor da produção de aguardente. Na primeira metade do séc. XIX, flutuação de preços atingiu também a exportação de cacau, algodão, arroz e vários produtos florestais (Cordeiro op.cit.; Barata 1915) e não havia sistema de crédito adequado ao plantio-manejo ecológico, nem à indústria de derivados do látex, que falia à medida que se desenvolvia a indústria estrangeira.

Os conflitos em torno da independência do Brasil agravaram o quadro de instabilidade. A adesão do Pará em maio de 1823 provocou um movimento social para o qual independência significava a tomada do controle do Estado pelos brasileiros. Muitos reivindicavam também o fim da escravidão e da concentração de riquezas nas mãos de uns poucos comerciantes, exportadores e fazendeiros, a maioria portugueses, britânicos e franceses. Esse movimento considerava a independência um acordo entre elites do Sudeste e o absolutista D. Pedro I. A repressão violenta aos protestos abriu caminho para a cabanagem (1835-40), guerra civil na qual a sociedade inteira lutou por um projeto alternativo de autodeterminação. Os cabanos foram vencidos com a ajuda dos britânicos (os navios de Guerra enviados pela França chegaram atrasados). Os bombardeios a Belém mataram 30\% de sua população e destruíram parte da cidade, enquanto milhares de pessoas no campo e na cidade foram presas, deportadas ou mortas. ${ }^{16} \mathrm{O}$ movimento cabano envolveu a ocupação e a destruição parcial de empresas de açúcar e fazendas, fato que, somado ao bombardeio de Belém, resultou em profunda crise econômica.

A conjuntura política nacional pós 1840 apenas agravou as dificuldades regionais. A coalizão de elites aliadas a D. Pedro II que assumiu o poder, promoveu a centralização política no Rio de Janeiro e da economia no Sudeste, enquanto conquistava o reconhecimento internacional através da submissão do país aos interesses econômicos e ideológicos de capitais internacionais (Domingues 1995; Linhares 1990; Holanda 1976; Fausto op.cit: cap.2). A racionalidade científica evolucionista moldou uma atitude oficial e um meio intelectual marcado pela busca de tecnologia, educação, costumes e ideologias européias consideradas símbolos do mais alto nível de evolução humana. Foi

${ }^{16}$ A participação dos ingleses nesses conflitos é discutida em detalhes por Bentes, 1998:caps. 3 e 5. Sobre os conflitos em torno da independência e a cabanagem veja Coelho 1978; Raiol 1970; Baena 1969; Paolo 1990; Cruz 1942; Salles 1968 e 1992; Reis 1965; Prado Júnior 1977. 
também um meio para as elites de legitimar o senso de superioridade que nutriam em relação à maioria dos brasileiros, sobretudo, aos amazônidas, considerados empecilhos à grandeza nacional. $\mathrm{O}$ vale do Amazonas era secundário nas políticas oficiais e as elites eram influenciadas por cientistas e intelectuais estrangeiros que usavam o preconceito verde (a visão de que povos capazes de estabelecer relações relativamente harmoniosas com florestas nativas seriam primitivos e incivilizados), o determinismo ambiental e o racismo para inventar o suposto primitivismo e inferioridade da região ${ }^{17}$. A noção de que cientistas europeus detinham a verdade sobre as leis da natureza e da sociedade humana era tão bem aceita que o governo imperial assimilou as idéias de um naturalista europeu para criar um símbolo de nacionalidade - uma história unificadora do Brasil. O naturalista definia os povos indígenas como civilizações avançadas que teriam degenerado a nível tecnológico e cognitivo primitivos no meio natural inferior do vale amazônico; eles não teriam alma e suas personalidades seriam deformadas (Spix \&Martius 1981).

Nesse contexto de instabilidade econômica e de dominação política e ideológica, comerciantes ambulantes e empresários rurais de pequeno e médio porte viram a alta de preços e os estímulos estrangeiros como oportunidade de investimento. Em 1868 a borracha já liderava a pauta das exportações, apesar dos seringalistas serem uma fração capitalista secundária - muitos empresários resistiram a essa produção por considerarem o sistema de comercializaçãofinanciamento um retorno a relações financeiras e comerciais coloniais.

Cada vez mais a posse de capital tornava-se fundamental na apropriação de seringal. Podia-se adquirir seringais através da compra de propriedades ou posses, ou de apossamento de seringais devolutos distantes. Estes exigiam investimentos: transporte e produtos de subsistência durante a safra (6 a 7 meses), construção de infraestrutura mínima e mão-de-obra especializada no trabalho inicial de identificação das espécies, nível de densidade das árvores e plano físico da empresa - estrutura dos caminhos de seringueiras, locais apropriados para armazém, porto, sede da empresa e cabanas para os seringueiros. O trabalho inicial durava no mínimo dois dias em seringais pequenos, se realizado por um mateiro (trabalhador especializado na localização e classifica-

\footnotetext{
${ }^{17}$ A visão da Amazônia por cientistas famosos é discutida por Gondim, op. cit.
} 
ção das árvores) e dois toqueiros (trabalhadores responsáveis pelo traçado dos caminhos). Em 1913, um mateiro recebia o equivalente a $£ 66.00$ por árvore identificada, e o toqueiro era um trabalhador assalariado cujo salário variava de $£ 100.00$ a $£ 120.00$ por mês. Se esse serviço durasse dois dias, o custo seria de $£ 265.00$ a $£ 332.45 .^{18}$

Obtinha-se empréstimo em casas exportadoras controladas por capitais ingleses e portugueses-alemães, casas aviadoras (comerciais-financeiras), bancos ou associações de crédito. As casas aviadoras tornaram-se as principais intermediárias no fluxo de crédito à produção, elas aceitavam o seringal e a borracha como hipoteca. Ao preferirem a hipoteca de extensos seringais e grande quantidade de borracha, elas reforçaram os privilégios dos empresários no processo de apropriação da terra. Sobretudo a partir de 1860, a borracha passou a atrair investidores nordestinos e estrangeiros, e a partir de 1870, casas aviadoras urbanas e comerciantes estrangeiros, sobretudo no início do séc. XX (Bentes 1998; Russan 1902; Dean 1989:81). Em 1913-15, casas aviadoras receberam vários seringais em pagamento de dívidas.

Estrangeiros investiam no comércio e financiamento da borracha, na produção em sociedade com seringalistas, na exploração de seringais alugados ou em arranchamentos que eram convenientes para não-residentes. Os arranchamentos exploravam, em particular, as florestas de Castiloa Ulie, cujo látex era usado para fazer caucho e os métodos de exploração exigiam a derrubada da árvore. ${ }^{19}$ Mesmo quando exploravam florestas de Hevea, eles tendiam a fazer cortes profundos, muitas vezes matando a planta. A partir da década de 1860, os presidentes do Pará e do Amazonas atacaram o problema através do estímulo à privatização empresarial de seringais devolutos, avaliando que a exploração predatória resultava da falta de senso de propriedade, pois os proprietários preservavam seus seringais. No Pará, em 1870-1910, esse estímulo foi associado à política de imigração de produtores de alimentos para o mercado interno e ao encorajamento à produção associada borracha-cereais (Bueno 1882; Moraes 1984; Conceição 1990; Lima 1986; Silva 1978:31-32).

\footnotetext{
${ }^{18}$ A conversão do réis para libra ilustra os altos valores envolvidos na produção de borracha e está baseada nas taxas apresentadas pelo IBGE 1990:591-598.

${ }^{19}$ A Castilloa Ulie era encontrada com abundância no alto Juruá e nos vales dos rios Purús, Madeira, Tapajós, Xingú e Araguaia (Mendes op. cit.).
} 
A expansão da borracha intensificou a demanda interna por alimentos, provocando alta no custo de vida, por ter atraído investidores e trabalhadores, aumentando a população regional, e atraindo produtores familiares locais, provocou a redução da produção de alimentos. ${ }^{20}$ Os seringais demandavam alimentos no mercado. Até a década de 1920, do total de 105 empresas de borracha existentes no Distrito do Rio Acre, 67\% produziam unicamente borracha. No Pará, em 1891-1942, do total de 2.927 propriedades, nos dez municípios maiores produtores do Estado, $41.5 \%$ especializaram-se nessa produção. O governo propunha produção diversificada também para prevenir migração, pois de 1872 a 1890 o Pará perdeu cerca de 32.000 habitantes na migração intra-regional. ${ }^{21}$ Finalmente, o governo visava a arrecadação de renda através da venda de terras devolutas. Eles encaminhavam essas propostas ao governo central, enquanto subsidiavam a imigração de seringueiros e a navegação.

O estímulo oficial à apropriação empresarial significou que os raros trabalhadores do seringal que ascenderam à posição de seringalista só o fizeram através de investimento de poupança no comércio ambulante, pagamento em prestações módicas e até casamento com a filha do seringalista (Cabral 1949; Neves 1981).

O produtor familial era secundário na apropriação dos seringais. No Acre, o trecho de seringais mais densos, localizado no Distrito do Acre, foi apropriado por 105 empresas pertencentes a empresários e firmas comerciais-financeiras. No Pará, embora produtores familiares possuíssem $37 \%$ das 2.927 propriedades existentes nos 10 municípios maiores produtores, suas propriedades continham apenas $18 \%$ do total de 19.915 caminhos de seringueiras (veja gráfico). Nas empresas, um caminho era composto de 100 a 200 seringueiras, enquanto os caminhos dos produtores familiares, de 40 a 80 . Cerca de $75 \%$ das propriedades empresariais eram de médio a pequeno porte, mas $24 \%$ dos donos possuíam de 2 a 11 propriedades e $59 \%$ associavam a borracha a outras culturas.

É duvidosa a idéia de que a propriedade empresarial teria sido produto dos últimos anos do boom da borracha no alto Amazonas, enquanto nas áreas mais antigas de produção no Pará os seringais teriam sido ocupados por produtores familiares (Weinstein op.cit.:45-46).

\footnotetext{
${ }^{20}$ A população do Pará aumentou 300\% no período de 1872 a 1906 (Silva 1978: 24).

${ }^{21}$ A análise mais completa de dados e bibliografia disponíveis sobre migração intraregional e imigração é aquela feita por Calixto 1993:83-92.
} 


\section{A Apropriação Ecológica Sob Pressão}

A produção ecológica da borracha parecia primitiva e irracional às elites educadas na tradição evolucionista tecnológica de pensar floresta preservada como símbolo de primitivismo e como racional a produção de baixo custo e altos lucros, não importando os custos ecológicos. Os relatórios do Ministro dos Negócios da Agricultura Comércio e Obras Públicas tratam da borracha na seção Indústria extrativa e, na década de 1860, um técnico propôs a monocultura e a mecanização desta (Dean op.cit). Foi, no entanto, o sentido científicoterritorial de terra na lei que mais afetou a apropriação dos seringais. A lei de terras herdou a tradição evolucionista do Direito português através da noção de função social da propriedade da terra (Maia 1999: 23-34) atrelada a um significado científico-territorial de terra e ocupação: colonização ou assentamento agrícola, vilas e cidades. E decorria da política do Segundo Reinado de estímulo à agricultura científica e pressão para que os brasileiros abandonassem métodos não-científicos, considerados primitivos e ineficientes (Domingues op.cit.). Nessa lei, ocupação e uso produtivo da terra - requerimentos para a legalização de posses e para a re-legitimação de sesmarias - significa cultivo.

A exigência de cultivo afetou a apropriação ecológica, pois, inicialmente, os seringais disponíveis eram na maioria devolutos. Apropriar seringais devolutos significava apossá-los segundo extensão territorial e uso definidos pela lei, medilos e requerer a legalização de posse, que era burocrática e morosa, executada por instituições situadas em cidades distantes, que forneciam título provisório a ser substituído por definitivo após comprovação de que a posse obedecia aos termos legais. O título tinha de ser registrado em cartório. Essa burocracia poderia tornar-se mais complicada, porque a apropriação ecológica contrastava com o significado legal de terra e de ocupação produtiva.

O significado de terra-seringal implicava que a densidade e a distribuição geográfica das seringueiras, e não a extensão do solo, definiam a extensão e os contornos da propriedade. Ávido por lucro, o seringalista definiu o tamanho de sua propriedade pelo potencial lucrativo da floresta: "Para ser lucrativo um seringal tem de ser extenso. Devido a heterogeneidade da floresta tropical e a dispersão das seringueiras, um seringal que emprega, 30 seringueiros, considerado um seringal pequeno, tem que ter pelo menos 9.000 seringueiras. Sua extensão seria de cerca de 10.000 hectares" (Bonfin op.cit.:14-47). Essa prática podia resultar em extensão territorial além daquela permitida por lei. Ademais, para o seringalista, usar um seringal produtivamente significa- 
va explorá-lo através de plantio-manejo ecológico e não de cultivo. Para garantir continuidade da produção, extraía-se o látex de modo a não danificar a seringueira, cuja saúde dependia também da preservação da ecologia do seringal, e repunham-se plantas velhas. Para aumentar a produtividade, cultivavam-se seringueiras e/ou outras culturas compatíveis à sombra da floresta ou através da abertura de pequenas clareiras apenas no início do plantio. As modificações desses métodos ao longo dos séculos XIX e XX não visaram as plantations e isto não se deve nem à falta de tino empresarial, nem às pragas nem à irracionalidade. Em todo o mundo, a monocultura tendia a desenvolver pragas, mas isto apenas encorajou cientistas a inventarem agrotóxicos cada vez mais potentes. A descoberta científica de que as plantas crescem mais rapidamente quando recebem luz do sol direta havia popularizado a crença de que o desmatamento seria necessário para garantir lucratividade e de que desmatar para a monocultura seria ato civilizatório. Em contraste, os seringalistas geralmente concebiam a ecologia do seringal nativo como um capital produtivo e desenvolviam técnicas para preservá-la e torná-la mais produtiva ao invés de destruí-la.

O governo evitou o tema, apenas fixando a extensão máxima da propriedade de seringal em 1860. Em 1874, tentou tratar da especificidade da apropriação ecológica, mas terminou reproduzindo a prática de compelir as pessoas a adotarem a agricultura científica através dos requerimentos para legalização de posses e revalidação de antigos títulos: cultivo como prova de uso produtivo da terra e a demarcação da extensão de solo, em vez de criar medidas adequadas à perspectiva ecológica, central na produção de borracha.

Em 1891, quando a primeira constituição republicana transferiu a administração de terras públicas para os Estados, o governo do Pará expediu o decreto que considerava a conservação de florestas extrativas e de pastos naturais, com exploração econômica permanente, prova de ocupação e uso produtivos da terra. O governo do Amazonas fez o mesmo em 1903.

Essas mudanças não beneficiaram a área mais importante produtora de borracha: o Distrito do Acre (Ministério da Agricultura, Indústria e Comércio 1913: 14-30; Chaves 1913:18; Prado Junior op.cit::236; Labre 1887). O Acre fazia fronteira com a Bolívia, o Perú e o Amazonas. Quando incorporado ao território brasileiro em 1904, tornou-se Território Federal regulado pela legislação federal, muito atrás das legislações do Pará e Amazonas no que diz respeito à apropriação ecológica. A incorporação foi marcada pela indiferença oficial às reivindicações dos brasileiros que haviam apropriado os seringais mais densos do Distrito do Acre, onde 60\% das propriedades (num total de 105) 
foram adquiridas no período de 1848 a 1907. Alegando imprecisão na fronteira física do Brasil com a Bolívia eles apropriaram terras de acordo com a legislação brasileira, mas o governo aceitou a soberania boliviana na área em 1867 (Tratado de Ayacucho). De 1889 a 1896, o governo boliviano instalou alfândega no Acre, assinou outro tratado que expandia a soberania boliviana, requereu que a propriedade fosse legitimada segundo suas leis (Duarte op.cit.:cap.1; Neves 1981:17) e negociou com o Bolivian Syndicate, um consórcio americano-inglês, a administração e o policiamento da área. Os seringalistas propuseram a anexação do Acre ao território brasileiro e empreenderam dois conflitos armados (Calixto op.cit.). O governo protestou quando o Bolivian Syndicate foi criado em 1901, mas manteve-se indiferente aos seringalistas. Somente quando o Barão do Rio Branco assumiu o Ministério de Relações Exteriores em 1902, a idéia de integração do Acre foi aceita.

Em 1904, o Acre foi incorporado ao território brasileiro num tratado que prevê o reconhecimento de propriedades adquiridas antes de sua assinatura (O Tratado de Petrópolis - 17 de Novembro de 1903. Petrópolis: ItamaratyRio 1903, art. II.). O reconhecimento da legalização de posses anteriores ao tratado prevaleceu durante um ano de arbitragem internacional. Quando a tarefa foi transferida para instituições federais, a possibilidade de anular legalizações anteriores ao tratado foi cogitada como meio de arrecadar taxas. O governo, sem rever a exigência de cultivo, tinha permitido o registro de posses em cartórios e permitido que seringais pudessem ser hipotecados.

Em 1906, cartórios de registros foram instalados no Acre (Magalhães op.cit.). A ambigüidade da lei tornava as transações com seringais mais complexas, pois eles eram avaliados prioritariamente pelo número de caminhos de seringueiras havendo casos de sobras de terras - extensão territorial da propriedade que não era coberta pelo título. Porém, um título de propriedade registrado em cartório só poderia ser contestado através de complexo e lento processo. O seringalista podia alegar ter incorporado nesgas de terras devolutas a sua propriedade, situada numa área de fronteira nacional, onde o direito brasileiro encorajava a privatização de grandes extensões de terras. A atitude das instituições federais quanto ao reconhecimento de títulos significou um empecilho a mais na reivindicação dos seringalistas. Por ser um território federal, o Acre não tinha representantes no congresso nacional, eles tiveram de lidar com esses problemas atuando junto ao Congresso e à Presidência da república através de seus advogados, senadores e deputados de outros Estados (Instituto Histórico 
e Geográfico Brazileiro doc. IHGB 190, 5,7 no. 24, doc. IHGB 200, 8,5, nº18, and doc. IHGB 100,9,8 no.15).

Era o apogeu das pressões sobre a apropriação ecológica. Um dos motivos para que elites militares tomassem o poder em 1889 foi o descontentamento com a monarquia por transferir oficiais de alta patente para a Amazônia. Eles tomavam a ida para a Amazônia como um exílio numa área à margem do Brasil civilizado. O segundo presidente republicano castigou oposicionistas transferindo-os para a Amazônia. O cerne da política da Primeira República (1889-1930) era a administração financeira para pagar débitos a bancos estrangeiros, o café e a industrialização do sudeste (Bentes 1998:cap. 5; Calixto op.cit.). ${ }^{22}$ De 1898 até 1920 , elites cafeicultoras no poder exarcebaram o atrelamento do Brazil-nação à racionalidade tecnológica desenvolvimentista. Em 1906, Euclides da Cunha, militar que havia chefiado a comissão de estudos sobre a fronteira nacional com a Bolívia, usou noções de evolução geológica, determinismo ambiental e preconceito verde (ele afirmava que a natureza Amazônica, inferior e selvagem, teria moldado pessoas sem qualidades físicas e morais e sem arte nem ciência) para argumentar a inferioridade da paisagem Amazônica em comparação a do Sudeste (Cunha op.cit.). A violência e a exploração nas relações de trabalho nos seringais, dizia ele, eram típicas de natureza selvagem. Ele ignora assim que a violência intrínseca à submissão de pessoas comuns à avidez de lucro dos capitalistas era fenômeno moderno e civilizado que caracterizava inclusive as rubber plantations. ${ }^{23}$

A racionalidade tecnológica desenvolvimentista constituía o terreno comum entre figuras importantes da Primeira República e os britânicos. Desde a década de 1860, o interesse do Império Britânico pelos recursos naturais tinha aproximado cientistas da burocracia imperial em torno da combinação racionalidade tecnológica desenvolvimentista e imperialismo verde - ações justificadas pela idéia de que florestas ricas em produtos naturais valiosos não manejadas cientificamente, estariam em estado bruto e sendo usadas inadequadamente por povos primitivos (Drayton op.cit.). Na década de 1870, eles iniciaram esforços para

\footnotetext{
${ }^{22}$ Sobre a Primeira República veja Saes 1985, 1977 e 1975; Sodré 1968; Casalecchi 1987; Silva 1981; Bello 1972; Fausto op. cit.:cap. 3; Carone 1988; Guanabara 1982; Carvalho 1981, 1990 e 1990a; Lessa 1988; Mercadante 1972; Queiroz 1986.

${ }^{23}$ Sobre relações de trabalho nos seringais veja Bentes, 1998 caps. 3 e 4.
} 
transformar métodos ecológicos de plantio de seringueiras em monocultura, o que conseguiram através de um jardim botânico - o Kew Garden (Bowler 1992; Brockway 1979; Hecht \& Cockburn 1989). No início do Século XX, eles já vendiam essa tecnologia. Cientistas e diplomatas tinham então novas preocupações. As rubber plantations surgiram sob forte dependência do suporte econômico e político do Estado Britânico e enfrentavam dificuldades que só foram resolvidas a partir de 1909 (Journal of the Society of Arts Jan/ 1906; Barlow 1978:27-30; Drabble op.cit.: cap. 2). As tentativas de cultivar borracha falharam em muitas áreas. O nível de produtividade no Ceilão era baixo (Dean 1989:76). Até 1907, empresários e financiadores não se impressionaram com as rubber plantations (Wright 1907:631), além das pestes, exaustão de solo e outros problemas que haviam frustrado as tentativas de cultivar café em larga escala na Malásia (Barlow op.cit.:29), eles temiam excesso de produção (Wright op.cit.) e pensavam que as rubber plantations eram empreendimentos para o Estado devido ao alto custo (Wright op.cit.:641). Em 1906, a Àsia tropical produzia apenas 3\% da borracha mundial (Wright op.cit.:615) e até 1909 financiamentos e investimentos eram insatisfatórios na Malásia (Barlow op.cit::29-31).

O Estado britânico intervinha diretamente na economia através de investimento pesado em pesquisa, infraestrutura de transporte-exportação e oferta de crédito e também através de campanhas para convencer os empresários sobre a eficiência das plantations, as quais foram marcadas por temor e tentativas de alijar a borracha amazônica.

Eles temiam que o acréscimo de investimentos estrangeiros em 1903-1913 e a existência de seringais distantes ainda não privatizados provocassem aumento da produção de espécies inferiores de borracha na Amazônia, pois eles acreditavam que o sucesso das rubber plantations dependia em grande medida do desempenho dessa produção já que a borracha de plantations não podia concorrer com a alta qualidade da borracha fina (Fina Hard Para) (Herbert Wright, ed., The India Rubber Journal ( 21 Sept. 1908; A Província do Pará out/1908). Em 1890, a Amazônia ainda produzia 84\% e em 1910-12, 57\% da borracha mundial; e no período de 1896-1906 a produção local aumentou a uma média anual de 6.5\% (Pará. Governo do Estado 1907). A borracha fina, que representava a maior proporção da borracha exportada pela região (Wright 1907:619-620; Journal of the Royal Society of Arts 1906:919; Collins 1896:82), era o tipo de maior demanda e comandava os preços (Wright op.cit.; 
Journal of the Royal Society of Arts op.cit.; Collins op.cit.; Coates op.cit.:52; Arquivo Histórico do Itamarati (AHI) vol. 270/215).

Em 1906, diplomatas ingleses cogitaram reduzir ou estancar a oferta de crédito por firmas britânicas na Amazônia, mas recuaram porque o vice-cônsul em Manaus alertou que firmas alemãs poderiam oferecer tais serviços imediatamente (F.O.368/172). Em publicações e debates na Royal Society of Arts em Londres, que reunia cientistas e empresários, a menção aos altos custos das rubber plantations era sempre seguida do argumento de que depois de 7 anos o lucro seria considerável. ${ }^{24}$ Em contraste, diziam eles, a produção de borracha na Amazônia tornar-se-ia cada vez mais cara devido à característica nomádica e predatória que exigiria, em futuro próximo quando as seringueiras mais próximas estivessem exauridas, jornadas cada vez mais longas para atingir novos seringais (Journal of the Royal Society of Arts (Jun. 1905): 643; (Dez.1905): 61-62; (Fev.1906):382). O argumento ignora que 80\% da produção regional não era nem nômade nem predatória, pois a privatização dos seringais significou a expansão da produção baseada na propriedade privada e o crescente desaparecimento dos arranchamentos. No início do séc. XX os seringais lucrativos acessíveis eram privatizados e o caucho variava de 16 a 20\% da borracha exportada anualmente pela Amazônia (Bentes 1998).

Na Primeira Exposição Internacional de Borracha, em Londres, em 1908, o Cônsul Britânico no Pará proclamou que "The term 'estate' and the idea of settled occupation the world calls up is misplaced when applied to the immense areas of desolated swamp land and virgin forest (...) As employed, it is misleading to European readers, who understand by the term 'estate' a property of scrupulously defined limits, exactly defined area and clearly established title deeds." (F.O. and The Board of Trade 1908:21-22). Por conceber a propriedade privada européia como o modelo a ser seguido, ele foi capaz de fazer tais afirmações sobre os seringais ao mesmo tempo em que afirmava não estar familiarizado com as leis brasileiras.

Seringalistas e mercadores protestaram contra a fala do Cônsul, mas as críticas foram mantidas como matéria confidencial pela diplomacia britânica.

\footnotetext{
${ }^{24}$ Para desmatar 500 acres de terra e plantar cerca de 108 árvores por hectare eram necessários 5,946 17s.6d. esterlinas, mais juros, e o investidor teria que esperar de 5 a 6 anos para começar a obter lucro.
} 
Ao defender-se, contradição e discriminação caracterizaram os argumentos do Cônsul. ${ }^{25}$ Ele se referiu aos seringalistas e comerciantes que pediam a intervenção do governo federal para neutralizar a interferência dos ingleses no mercado local de borracha como 'childish,', um termo usado por antropólogos evolucionistas para descrever o estado de suposto subdesenvolvimento tecnológico e cognitivo dos povos indígenas (F.O.368/274). Os seringalistas pediam apenas que o estado brasileiro fizesse o que o estado britânico fazia há muito: intervir na economia da borracha.

Ao tentar provar o "primitivismo" dos seringalistas em contraste com a "civilidade" das plantations, o Cônsul visava atrair investimentos para estas. O preconceito verde expresso na caracterização dos seringais como "desolated swamps and virgin forest", o racismo e a atitude hierárquica autoritária reflete quão estranha a aparência de floresta intocada dos seringais parecia a pessoas acostumadas à natureza cientificamente dominada: propriedades rurais que pareciam blocos de solos expostos, periodicamente cobertos com monocultura. O oeste europeu era caracterizado pela quase completa ausência de florestas nativas. E nas colônias britânicas, extensas áreas estavam sendo desmatadas para as rubber plantations - em 1910-15, 3 milhões de acres foram desmatados no sul e sudeste asiático (McHale op.cit.:20; Barlow op.cit.:22). Já em meados do séc. XIX, Wallace havia manifestado o desejo de controle sobre a Amazônia conjecturando o quanto seria fácil para povos superiores das zonas de clima temperado transformar suas florestas e campinas em monocultura, atribuindo a quase inexistência desta à indolência e falta de mão-de-obra ( Wallace op.cit.: 60 e 208; Gondim op.cit: 134-35). ${ }^{26}$ Em 1870, ele repensou o evolucionismo social somente para afirmar que os primitivos modernos seriam mentalmente iguais à raça branca, porém, diferentemente desta, eles não colocavam a capacidade mental em uso (Bowler 1989:230). Os princípios desenvolvimentistas influenciaram até Karl Marx, que acreditava ser a indústria capitalista estágio superior da evolução humana e o começo da história e, sociedades não industriais, primitivas ou "mere hunting and fishing peoples lie outside the point where real development begins”( Marx 1973:107; Marx 1974:112-13).

\footnotetext{
${ }^{25}$ Em especial dois artigos criticaram o Cônsul: A Província do Pará out. 1908 e nov. 1908.

${ }^{26}$ Sobre Wallace veja também Arnold 2000: cap. 2.
} 
Nesse momento, a visão ecológica dos seringalistas era particularmente óbvia. O representante da Associação Comercial do Amazonas no evento de 1908 dizia que os métodos de fazer borracha nas plantações asiáticas deveriam ser avaliados cuidadosamente a fim de aperfeiçoar os métodos usados na Amazônia. Essa avaliação, todavia, deveria estar baseada na experiência local com os métodos de plantio-manejo ecológicos. Ele enfatizava a unanimidade dos seringalistas em criticar o método científico de corte da seringueira: "O corte é muito longo e a árvore sofre com isso, particularmente na parte mais alta do tronco onde a umidade não é tão alta (...) Pelo sistema "half herring -bore" adotado nas plantações de borracha o corte é de 60 polegadas. Pelo sistema usado na Amazônia o corte é de no máximo 2 polegadas. Mesmo assim, não há seringueiro experiente na Amazônia que discorde que mesmo as árvores cortadas com o maior cuidado têm sua produção reduzida com o tempo" (Revista da ACA (Editorial), nov./1908:3). No Pará, seringalistas já haviam processado ingleses por terem alugado seus seringais e morto seringueiras pelo uso do método científico de corte (Tribunal de Justiça do Estado do Pará. Autos Civis, 1877-1922). Em 1910, no Congresso do Comércio, Indústria e Agricultura realizado em Manaus, considerando o desmatamento desnecessário, seringalistas foram unânimes em aprovar o método pelo qual pequenas nesgas eram abertas dentro da floresta somente nos estágios iniciais de cultivo o que propiciava aumento de produtividade sem que a floresta fosse destruída (Miranda 1990).

Aqueles que rejeitaram a advocacia das plantations foram negligenciados até pela comissão criada pelo congresso brasileiro em 1906 para propor uma política para a borracha. Na comissão e em discussões posteriores, somente aqueles organizados em torno da preocupação com altos níveis de produtividade e com a arrecadação de rendas públicas conseguiram se fazer ouvir. $\mathrm{O}$ presidente da comissão condenou o caráter explorador do que ele chamou de sistema dos patrões para recomendar a sua substituição pelas plantations, que considerava cultivo racional, como se o plantio-manejo ecológico fosse irracional e as relações de trabalho nos seringais seu produto direto. ${ }^{27} \mathrm{O}$ Plano de Defesa da Borracha, e a lei de 1908, reduziu impostos incidentes sobre a borracha e a importação de alimentos e incentivou o uso da borracha brasileira

${ }^{27}$ Sobre esse debate veja também Silva 1978 e Dean op. cit. 
no mercado. O Plano, todavia, refletia o evolucionismo economicista de perseguir desenvolvimento através da importação de tecnologia e a preocupação em manter a borracha brasileira competitiva no mercado, não a valorização e promoção das particularidades da produção ecológica de borracha. Promoveram-se as rubber plantations em todo o Brasil e isentou-se de taxas a importação de tecnologia destinada a essa atividade. As indústrias amazônicas - a exemplo da indústria de latinhas para a extração do látex - tiveram de protestar contra a competição desigual a que foram expostas, e aqueles que reivindicavam suporte público para as inovações tecnológicas locais no preparo da borracha foram ignorados. Eles não foram desconhecidos pelos americanos, todavia, que testaram, premiaram e absorveram esse conhecimento, ao modo deles e de graça. O Plano atendeu prioritariamente aos interesses daqueles que comungavam a racionalidade oficial: estrangeiros e brasileiros interessados nas plantations, fazendeiros do Marajó e comerciantes urbanos. Ignorou-se o argumento do investidor estrangeiro: a causa da falência de muitas empresas pertencentes a estrangeiros resultava do seu despreparo para administrar a singularidade dos seringais (Russan op.cit.). Em 1912-14, os 50 proprietários de terras que se propunham a investir em rubber plantations, então promovida por Akers, um expert, eram na maioria estrangeiros (Comissão de Investigação do Vale do Amazonas 1912; Akers 1912). Companhias de origem estrangeira o contrataram para ensinar técnicas, além de terem mediado seus esforços para adquirir terra para a construção de escola de rubber plantations (Carta de H.C. Rendle para George Booth - Adephi Terrace House, Adelphi Terrace, Londres, 20 de October de 1912). Autores americanos propuseram a adaptação às rubber plantations ou a modernização dos seringais a fim de reduzir preços (Wooddroffe \& Smith 1915; Hale 1915; Hassel, "Tapping Trees by Eletricity," Indian Rubber World 47(2):142-43; Coomes \& Barham op.cit.). O estímulo oficial à monocultura beneficiou, na década seguinte, o Projeto Ford que implementou a monocultura maciça, devastando o meio ambiente (Schmink 1988). Quando os incentivos oficiais cessaram, Ford vendeu o projeto a um consórcio brasileiro que produziu borracha lucrativa até pelo menos a década de 1980 (Neves, 1985).

Os seringalistas concordaram com o Plano de Defesa da Borracha na redução de impostos e na questão fundiária. O Plano removeu as barreiras ao reconhecimento da propriedade no Acre. A distinção entre domínio, soberania, e jurisdição sustentou o reconhecimento de títulos antigos de propriedade de terra pela União (Magalhães op.cit.). O status de propriedade privada dos 
seringais ficou evidente nos resultados de pesquisa recente do INCRA-Acre que mostra que os 105 seringais do distrito do Acre ocupavam uma área total de 1.760.357 ha, sendo 1.070.569 ha constantes de escrituras antigas de propriedade. O governo reconheceu a legalidade do total de 1.592 .677 ha, enquanto 552,109 ha foram objeto de estudo e classificação especial, sendo, no final, apenas 44.230 ha resgatados sob a alegação de ausência de prova legal de propriedade, e o status legal do total de 477,879 ha está pendente de decisão judicial. O seringal era, sim, propriedade privada.

Eles alegavam, porém, que a solução dos problemas da borracha não estava na adoção da monocultura, mas na redução do custo de vida dos seringueiros e de produção através da redução de impostos, da oferta de crédito compatível com plantio-manejo ecológico, da melhoria da infraestrutura e custo de transporte, da oferta de serviços públicos de saúde e educação (ACP, Relatórios anuais; "O Problema do Norte", Coluna GAZETILHA, Folha do Norte, Belém, 26 de abril de 1913, 1). Em livro, um seringalista questionou os métodos científicos, defendendo os ecológicos (Chaves op.cit.:37-40). Entre a próxima geração de seringalistas estava Carlos Neves, filho de um seringalista, educado na perspectiva científica. Agrônomo frustrado com a indiferença dos seringalistas à sua proposta da monocultura da borracha em áreas adequadas, ele insistia que a falta de pesquisa suficiente para desenvolver clones resistentes a pragas, insuficiência de capital e falta de crédito adequado certamente influenciaram na não proliferação da monocultura da borracha na Amazônia; a razão principal, todavia, era que os seringalistas não queriam adotar a monocultura por considerá-la predatória (Neves 1958, 1958a, 1958b, 1958c e 1985). Os seringalistas o criticavam pelo experimento com essa tecnologia em 200ha de sua propriedade (Neves 1981).

Bem mais tarde, Neves, filho de seringalista e agrônomo, argumentou que não teriam sido as pragas a razão principal dos seringalistas não terem adotado a monocultura, mas por considerá-la predatória (Neves 1958, 1958a e 1958b; 1958c e 1985). Eles o criticavam pelo experimento com essa tecnologia em 200 ha de sua propriedade (Neves 1981).

Essas vozes foram silenciadas, prevalecendo o estigma do método ecológico de plantio-manejo como primitivo e ineficiente.

O Plano de Defesa da Borracha não foi incluído pelo Congresso no Orçamento da União para o ano seguinte, interrompendo os serviços de 
infraestrutura que tinham sido iniciados e inviabilizando essa política (Martinelo op.cit.:57).

O colapso da política oficial não significou o colapso da produção. A crise de preços da borracha de 1912-15 levou à falência casas aviadoras e muitos seringais, além de afugentar capitais estrangeiros. Os seringalistas, todavia, há muito vinham criando estratégias para lidar com os efeitos das flutuações de preços seguidas de crises econômicas. Os melhores seringais continuaram a exportar borracha, inclusive para o Reino Unido, durante todo o auge das plantations e foram lucrativos até pelo menos o início da década de 1980 (Bentes 1998).

\section{Conclusão}

Visões conflitantes de natureza, propriedade e tecnologia marcaram a história da apropriação dos seringais na Amazônia de 1840 até às primeiras décadas do séc. XX. A apropriação dos seringais era ecológica - a modernidade do status social da terra-seringal de capital produtivo e mercadoria valiosa, cujo acesso, socialmente desigual, seguia os padrões legais do resto do Brasil, misturava-se ao significado de terra como a floresta de goma elástica, o que definia o tamanho e os contornos da propriedade. Favorecidos pela posse de capital ou crédito, estímulo estrangeiro e certos privilégios legais, empresários, mais do que produtores familiares, apropriaram os seringais.

O significado ecológico de terra chocou-se com o sentido científicoterritorial que norteava a defesa das plantations pelo Estado e pelos britânicos: solo a ser desmatado para a monocultura. Os britânicos exaltaram a civilidade das plantations em contraste com a suposta incivilidade dos seringais, percepção comungada pelas elites cafeicultoras no poder. A política oficial para borracha promoveu as plantations.

\section{Bibliografia}

A Província do Pará. 'A Nossa Borracha', Jornal A Província do Pará. Belém, 02 de novembro de 1908.

A Província do Pará."A Borracha - O Pará e seu Comércio". A Província do Pará. Belém, 25 de outubro de 1908.

A Província do Pará.”A Extração da Borracha e seu Futuro no Amazonas". A Província do Pará, 28 de outubro de 1908, Coluna Assuntos Oportunos. ASSOCIAÇÃO COMERCIAL DO PARÁ (ACP). Relatórios Anuais 1867-1915. 
ACUNÃ, Cristoval de. Voyages and Discoveries in South America, the First Up the River of Amazons to Quito in Peru, and Back Again to Brazil. London: C. Buckley, 1698.

AKERS, Charles. Report on the Amazon Valley: Its Rubber Industry and Other Resource, London, Waterlow and Sons, 1912 (Versão em Português: Relatório sobre o Valle do Amazonas, Sua Indústria da Borracha e Outros Recursos, Rio de Janeiro: Jornal do Comércio, 1913).

AKERS, Charles. The Rubber Industry in Brazil and the Orient, London, Mathew and Co. Ltd., 1914.

ALMEIDA, Maria de. “Os Vassalos D’El Rey nos Confins da Amazônia - A Colonização da Amazônia Ocidental, 1750-1798". Niteroi, UFF, 1990 (Dissertação de Mestrado).

ARNOLD, David. The Age of Discovery 1400-1600. London, Routledge, 2002.

BAENA, Antônio. Compêndio das Eras da Província do Pará, 2nd. ed. Belém, UFPa, 1969 c1829.

BALÉE, William. "The Culture of Amazonian Forests", em POSEY, Darrel \& William Balée, eds. Resource Management in Amazonia: Indigenous and Folk Strategies. New York, The New York Botanical Garden, 1989:1-21.

BARATA, Manuel. A Antiga Produção e Exportação do Pará - Estudo HistóricoEconômico. Belém, Torres \& Cia., 1915.

BARHAM, Bradford \& O. Coomes. "Reinterpreting the Amazon Rubber Boom", Latin American Research Review 29(2), 1994: 73-109.

BARLOW, Colin. The natural rubber industry. Kuala Lumpur, Oxford University Press, 1978.

BARNES, Barry \& S. Shapin. Natural Order: Historical Studies of Scientific Culture. Beverly Hills and London, Sage Publications, 1979.

BASTOS, Antônio. Cartas de Um Solitário. S. Paulo, Cia. Ed. Nacional, 1938 (c1863).

BATES, Henry. Um Naturalista no Amazonas. São Paulo, USP,1979.

BELLO, José. História da República (1889-1954). São Paulo, Companhia Editora Nacional, 1972.

BENOLIEL, Roberto. "A Borracha do Amazonas na Exposição de Londres". Revista da Associação Comercial do Amazonas (5 de novembro de 1908). 
BENTES, Rosineide. "Apropriação Geomercantil da Terra," in LUSOTOPIE 1996", L'Oppression Paternalist au Brésil, Paris (France), KARTHALA, 1996:163-172.

BENTES, Rosineide. "Campesinato e Fronteira: Para além da Fronteira". Belém, UFPa, 1991 (Dissertação de mestrado).

BENTES, Rosineide. "Frontier Approaches to the Amazon: Historical Denial and the Invisibility of Regional Society", artigo apresentado na Brazilian Studies Committee Roundtable, Conferência da American Historical Association (AHA), São Francisco, California, janeiro de 2002.

BENTES, Rosineide. "Rubber Enterprises in the Brazilian Amazon, 1870-1930". Londres, LSE, 1998 (Tese de doutorado).

BONFIN , Socrates. "Um Esboço da Vida Amazônica," in Brasil, Presidência da República, Valorização Econômica da Amazônia, Subsídios para o seu Planejamento. Rio de Janeiro, Departamento de Imprensa Nacional, 1954:14-47 BOWLER, Peter. Biology and Social Thought: 1850-1915. Berkeley, The Regents of the University of California, 1993.

BOWLER, Peter. Charles Darwin - The Man and His Influence. Oxford, UK; Cambridge, Massachusetts, Basil Blackwell, 1990.

BOWLER, Peter. Evolution. Berkeley, Los Angeles, London, University of California Press, 1989.

BOWLER, Peter. The Environmental Sciences. London, Fontana Press, 1992.

BOWLER, Peter. The Invention of Progress. Oxford, UK; Cambridge, Massachusetts, Basil Blackwell, 1989 c1983.

BOWLER, Peter. The Non-Darwinian Revolution. Baltimore and London, The John Hopkins University Press, 1988.

BRANCO, José. "O Gentio Acreano". Revista do IHGB 207(1950):3-77

BRANCO, José. “Acreania”. Revista do IHGB 240(1958):3-83.

BROCKWAY, Lucile. Science and Colonial Expansion: The Role of the British Royal Botanic Gardens. New York, Academic Press, 1979.

BUENO, M. Indústria Extractiva. A Borracha. Rio de Janeiro, Typografia Imperial e Constitucional de J. Villeneuve \& Cia., 1882.

CABRAL, Luis. DezAnos no Amazonas, 1897-1907. Paraíba, Escola Industrial, 1949. 
CALIXTO, Valdir. “Aquiri (1898-1909): Os Patrões e a Construção da Ordem”. S. Paulo, USP, 1993.

CARONE, Edgar. A República Velha I . Rio de Janeiro, Bertrand Brasil S.A., 1988.

CARVAlHO, José de. A Construção da Ordem - A Elite Política Imperial. Brasília, Editora Universidade e Brasília, 1981.

CARVALHO, José de. A Formação das Almas - O Imaginário da República no Brasil. São Paulo, Companhia das Letras, 1990.

CARVALHO, José de. Os Bestializados. O Rio de Janeiro e a República no Brasil. São Paulo, Companhia das Letras, 1990a.

CASALECCHI, José. O Partido Republicano Paulista - Política e Poder (18891930). São Paulo, Editora Brasiliense S.A., 1987.

CHAVES, Avelino. Exploração da Hevea no Território Federal do Acre. Rio de Janeiro, publicação particular, 1913 (Monografia Apresentada na Exposição Nacional de Borracha).

COATES, Austin. The Commerce in Rubber: The first 250 years. Singapore, Oxford University Press, 1987.

COELHO, Geraldo. "Ação e Reação na Província do Pará: O Conflito Social de 1823”. Niterói, UFF.ICHF, 1978 (Diss. de mestrado).

COLLINS, J. "On India-Rubber, Its History, Commerce, and Supply". Journal of the Society of Arts, 18 (Dez. 1896): 81-93.

Comissão de Investigação do Vale do Amazonas (Charles Edmond Akers, H.C. Rendle and F. Lugones). $O$ Vale do Amazonas. Publicação privada, 1912, cópia na livraria do Museu Nacional, Rio de Janeiro.

CONCEIÇÃO, Maria da. "Políticas e colonos na Bragantina, Estado do Pará: um trem, a terra e a mandioca”. Campinas, UEC, 1990 (Dissertação de mestrado).

COOMES, T. \& B.Barham. "The Amazon Rubber Boom: Labor Control, Resistance, and Failed Plantation Development Revisited." Hispanic American Historical Review 74(2)1994: 231-257.

CORDEIRO, Luiz. O Estado do Pará, seu comércio e indústrias de 1717 a 1920. Belém, Tavares Cardoso \& Cia.,1920.

CRONON, William, ed., Uncommon Ground: Rethinking the Human Place in Nature (New York: W.W. Norton and Co., 1996.

CRUZ, Ernesto. História do Pará. Belém, Governo do Pará, 1973. 
CRUZ, Ernesto. Nos Bastidores da Cabanagem. Belém, Oficina Gráfica da Revista de Veterinária, 1942.

CUNHA, Euclides da. À Margem da Historia. Lisboa, Livraria Lollo \& Irmão Editores, 1946, c1909.

DANIEL, João. Tesouro Descoberto no Rio Amazonas (Rio de Janeiro: Biblioteca Nacional, 1976), vol. 2.

DAVIES, Norman. The Isles. Oxford, Orford University Press, 1999.

DEAN, Warren. A luta pela borracha no Brasil - um estudo de história ecológica. São Paulo, Nobel, 1989.

DEAN, Warren. "Latifundia and Land Policy in Nineteenth Century Brazil," Hispanic American Historical review 51(Nov.1971):606-25.

DENEVAN, William. "Ecological Heterogeneity and Horizontal Zonation of Agriculture in the Amazon Floodplain", in Schimink Marianne \& C.H. Wood, eds. Frontier Expansion in Amazonia, Gainsville, University of Florida Press, 1984.

DOMINGUES, Heloisa. "Ciência: Um Caso de Política”. São Paulo, USP, 1995 (Tese de doutorado).

DOS SANTOS, Wanderley Guilherme. Ordem Burguesa e Liberalismo Político. São Paulo, Duas Cidades, 1978.

DRABBLE, John. Rubber in Malaya 1876-1922 - The Genesis of the Industry. London, Oxford University Press, 1973.

DRAYTON, Richard. Nature's Government. New Haven/London, Yale University Press, 2000.

DUARTE, Hélio. Conflitos pela Terra no Acre.Rio Branco, Casa Amazônia, 1987.

EDEN, Michael, D. McGregor, e N. Vieira.'Pasture development on cleared forest land in northern Amazonia”. Geographical Journal 156(3) 1990:283-296.

EDWARDS, William. A Voyage up the River Amazon. Philadelphia, G. S. Appleton, 1847.

EMMI, Marília. A Oligarquia do Tocantins e o Dominio dos Castanhais. Belém, CFCH/NAEA, 1988.

F.O. and The Board of Trade, Brazil, Report on the Trade of the Consular District of Pará: Diplomatic and Consular Reports, London, Harrison \& Sons, 1908.

F.O. and The Board of Trade, Diplomatic and Consular Reports - Brazil - the Trade of Pará District. London, Harrison \& Sons, 1902. 
FALCÃO, Emílio. Album do Rio Acre, 1906-07. Pará, s/d. (Disponível no Museu da Borracha em Rio Branco/Acre).

FAUSTO, Boris. A Concise History of Brazil. Cambridge (U.K), Cambridge University Press, 1999.

FERREIRA E CASTRO. A Selva. Lisboa, Guimarães Editores Ltda, 1955, c1930.

FERREIRA, Alexandre. Viagem Filosófica às Capitanias do Grão-Pará, Rio Negro, Mato Grosso e Cuiabá, Edited by Edgard de Serqueira Falcão. São Paulo, Gráficos Brunner, 1970.

Folha do Norte. "Debate sobre o Problema da Borracha". Jornal Folha do Norte. Belém, 16 de abril de 1913.

FONSECA, José. 'Navegação feita da cidade do Grão-Pará até à bôca do Rio da Madeira pela escolta que por êste rio subio às minas de Mato-Grosso', translated as 'Voyage made from the City of the Gram Para to the Mouth of the River Madeira by the Expedition which Ascended this River to the Mines of Mato Grosso..., in Explorations Made in the Valley of the River Madeira, from 1749 to 1868. A Collection of Reports. Edited by George Earl Church. London, Published for the National Bolivian Navigation Company, 1875, 203-355.

FRECHIONE, John, Darrel Posey e Luiz F. Da Silva, "The Perception of Ecological Zones and Natural Resources in the Brazilian Amazon: An Ethnoecology of Lake Coari," em Darrel Posey e William Balée, eds. 1989:260-281.

FURTADO, Celso. Formação Econômica do Brasil, Rio de Janeiro, Fundo de Cultura, 1959

GONDIM, Neide. A Invenção da Amazônia. São Paulo, Marco Zero, 1994.

GORENDER, Jacob. O Escravismo Colonial. São Paulo, Àtica, 1978.

GRAHAM, Robert. "Sepoys and Imperialist Techniques of British Power in Nineteenth Century Brazil”. Inter-American Economic Affairs, 23(1969):23-37.

GROVE, Richard. Green Imperialism. Cambridge; New York, Cambridge University Press, 1995.

GUANABARA, Alcindo. A Presidência Campos Sales: Política e Finanças, 18981902. Rio de Janeiro, Laemmert e Companhia, 1982.

GUEDES, Mario. Os Seringais. Rio de Janeiro, Jacintho Ribeiro dos Santos' 1920.

GUSDORF, Georges. Les Principes de la Pensée au Siécle des Lumieres. Paris, Payot, 1971. 
HALE, Albert. "Developing the Amazon Valley". Bulletin of the Pan American Union 36(1915):38-47.

HASSEL, George von. “Tapping Trees by Electricity”. Indian Rubber World 47:2 (1912), 142-43.

HECHT, Susanna \& A.Cockburn.The Fate of the Forest. London, Verso, 1989.

HEMMING, John. Amazon Frontier: The Defeat of the Brazilian Indian. Cambridge, Mass., Harvard University Press, 1987.

HOLANDA, S.B. História Geral da Civilização Brasileira. São Paulo, Difel, 1976.

IDESP (Bentes, Rosineide). "Perfil da Ocupação dos Castanhais". Belém, IDESP, Edição Especial da Revista Pará Agrário,1992.

IBGE (Fundação Instituto Brasileiro de Estatística). Estatísticas Históricas do Brasil. Rio de Janeiro, IBGE, 1990:591-598.

IBGE (Fundação Instituto Brasileiro de Geografia e Estatística). Introdução Industria Extrativa, 1907. Rio de Janeiro, Edição fac-similar, Séries Estatísticas vol. 2:2-3.

IDESP (Rosineide Bentes), "Perfil da Ocupação dos Castanhais". Belém, IDESP, Edição Especial da Revista Pará Agrário, 1992.

IGGERS, G. Historiography in the Twentieth Century: From Scientific Objectivity to the Postmodern Challenge. Hanover/London, Wesleyan Univeristy Press, 1977.

Journal of the Royal Society of Arts."Production of India-Rubber". Journal of the Royal Society of Arts, August 10, 1906.

Journal of the Royal Society of Arts.'Rubber Planting".Journal of the Society of Arts. January 26, 1906, pp. 272-73.

Journal of the Royal Society of Arts, 1905, vol. LI.

Journal of the Royal Society of Arts, 1905, vol. LIV.

Journal of the Royal Society of Arts, 1906, vol. LIV.

LABRE, Antônio. Itinerário da Exploração do Purus ao Beni. Pará, 1887.

LAPA, José. O Brasil e as drogas do Oriente. Marília, Faculdade de filosofia, ciências e letras, 1966.

LESSA, Renato. A Invenção Republicana. São Paulo, Vértice e Rio de Janeiro, IUPERJ, 1988.

LIMA, E. "Produção de Alimentos e Extrativismo, 1850-1920". Rio de Janeiro, UFRJ, 1986 (Dissertação de mestrado). 
LINHARES, M. História Geral do Brasil. Rio de Janeiro, Campus, 1990.

MAGALHÃES, J. Discriminação de Terras na Amazônia (O Acre). Brasília, publicação privada, 1977.

MAIA, J. "As Influências do Direito Português no Direito Agrário Brasileiro," in Laranjeira, Raymundo, ed. Direito Agrário Brasileiro. São Paulo, Ltr, 1999:23-34.

MARTINELO, Pedro. A Batalha da Borracha na Segunda Guerra Mundial e Suas Consequencias para o Vale Amazonico. Rio Branco,UFA, 1988.

MARX, Karls. Grundisse: Foundations of the Critique of Political Economy. England, Pinguim, 1973.

MARX, Karls. O Capital. São Paulo, Civilização Brasileira, Livro 3, vol. 5, 1974.

McHALE, T. Rubber and the Malaysia Economy. Singapore, M.P.H. Printers Sendirian Berhard, 1967.

McLEISH, John. Number - From Cave People to Computers, a Revolucionary View of Ourselves. London, Bloomsbury, 1991.

MEDINA, José. The Discovery of the Amazon According to the Account of Friar Gaspar de Carvajal and Other Documents. Translated by Bertran E. Lee. Editos H.C. Heaton. New York: American Geographical Society, 1934.

MELVILLE, Elinor. A Plague of Sheep. Cambridge, Mass., Cambridge University Press, 1994.

MENDES, José. Extração e Futuro da Borracha no Valle do Amazonas. Pará, Imprensa Libanio da Silva Lisboa, 1910.

MERCADANTE, Paulo. A Consciência Conservadora no Brasil. Rio de Janeiro, Civilização Brasileira, 1972.

Ministério da Agricultura, Indústria e Comércio, Relatório sobre as Condições Médico-Sanitárias do Valle do Amazonas pelo Dr. Oswaldo Cruz. Rio de Janeiro. Tipografia do Commércio, 1913.

MIRANDA, B.ed. Anais do Congresso Comercial, Industrial e Agrícola (22 a 27 de fevereiro de 1910). Manaus, Associação Comercial do Amazonas, Fudo Editorial, 1990.

MORAES, Ruth. "Transformações Demográficas numa Economia Extrativista: Pará, 1872-1920”. Curitiba, UFPr, 1984, (Dissertação de mestrado).

MOREIRA NETO, Carlos. Índios da Amazônia, de Maioria a Minoria (17501850). Petrópolis, Vozes, 1988. 
MOURA, Inácio de. De Belém a São João do Araguaia: Vale do Rio Tocantins. Belém, Secretaria de Estado de Cultura, 1989.

MULKAY, Michael. Science and the Sociology of Knowlegde. London, Allen and Unwin, 1979.

NASCIMENTO, Carlos \& A.Homma. Amazonia: Meio Ambiente e Technologia Agrícola. Belém, EMBRAPA-CEPATU documento 27, 1984.

NEVES, Carlos. "A Amazônia e a Hevea". Jornal O Rio Branco, 14 de dezembro de 1985.

NEVES, Carlos. "A Cultura da Seringueira nos Seringais Nativos". Rio Branco, Federeção das Associações Rurais do Território do Acre, 1958.

NEVES, Carlos. "A Seringueira". Jornal O Acre, 29 de dezembro de 1958c.

NEVES, Carlos."Borracha: Programa Prindipal do Novo Titular do Departamento de Produção". Jornal do Acre, 12 de junho de 1958b.

NEVES, Carlos. Memórias de um Pioneiro. Rio de Janeiro, publicação privada, 1981.

NEVES, Carlos."Vamos Plantar Seringueira". Jornal do Acre, 12 de janeiro de 1958a.

NEVES, Carlos. "Memórias de Um Pioneiro". Rio de Janeiro, mimeo, 1981.

NORONHA, José de (1768) na Colleção de Notícias para a História e Geografia das Nações Ultramarinas. Lisboa, Academia Real das Ciências - Tomo VI, 1856.

OLIVEIRA FILHO, J. “O Caboclo e o Brabo”. Revista da Civilização Brasileira, 11, 1979:101-140.

OLIVEIRA, Adélia. "The Evidence for the nature of the Precess of Indigenous Deculturation and destabilization in the Brazilian Amazon in the Last three Hundreds Years: Preliminary Data", em ROOSEVELT, Anna, ed., Amazonian Indians from Prehistory to the Present. Tucson, The University of Arizona Press, 1994:95-119.

PAGDEN, Anthony. Lords of all the World: Ideologies of Empire in Spain, Britain and France c.1500-c.1800. New Haven \& London, Yale University Press, 1995.

PALLADINO, Paolo e Michael Worboys, "Science and Imperialism", ISIS 84, 1993:91-102.

PAOLO, Pasquale Di. Cabanagem: a revolução popular da Amazônia, 2nd. ed. Belém, CEJUP, 1990 c1985.

Moreira Neto 1988; Hemming 1987, part 1. 
PARÁ.Governador do Estado (Augusto Montenegro). Mensagem à Assembléia Legislativa em 07 de setembro de 1907. Belém, Imprensa Oficial do Estado, 1907.

PARKER, Eugene, ed., "The Amazon Caboclo: Historical and Contemporary Perspectives". Studies in Third World Societies 32, 1985.

PORRO, Antônio. "Social Organization and Political Power in the Amazon Floodplain: The Ethnohistorical Sources", in Roosevelt, Anna ed., op.cit.:79-94.

PRADO JUNIOR , Caio. História Economica do Brasil. São Paulo, Brasiliense,1956.

PRADO JUNIOR Evolução Política do Brasil. São Paulo, Brasiliense, 1977.

QUEIROZ, Suely. Os Radicais da República. São Paulo, Editora Brasiliense, 1986.

QUINTILIANO, Antonio. Grão Pará - Resenha Histórica, 1616-1963. Belém, Imprensa Universitária do Pará, 1963.

RAIOL, Domingos A. Motins Políticos; ou história dos principais acontecimentos politicos da Província do Pará desde o ano de 1821 até 1835, 2nd. ed. Belém, UFPa, 1970, 3 vols., c1965.

REIS, Arthur. "Roteiro Histórico das Fortificações no Amazonas", Revista do Serviço do Patrimônio Histórico e Artístico Nacional 6 (1942):119 e seguintes.

REIS, Arthur. A Amazônia e a Cobiça Internanacional. Rio de Janeiro, Civilização Brasileira, 1982.

REIS, Arthur. A Amazônia que os portugueses Revelaram. Rio de Janeiro, Ministério da Cultura, 1957.

REIS, Arthur. A Política de Portugal no vale Amazônico. Belém, 1940.

REIS, Arthur. O Seringal e o Seringueiro. Rio de Janeiro, Serviço de Informação Agrícola, 1953.

REIS, Gustavo. A Cabanagem: um Episódio de Guerra Insurrecional na Amazônia. Manaus, Imprensa Oficial,1965.

Revista da ACA. Editorial "A Borracha do Amazonas na Exposição de Londres". Revista da Associação Comercial do Amazonas 5 (Nov.1908):1-6.

Revista da ACP. "Diversas Espécies de Seringueiras. Clima e terrenos apropriados". Revista da Associação Comercial do Pará (set.out/1927).

Revista da ACP.'Zona de Fronteiras - Terrenos Ribeirinhos". Revista da Associação Comercial do Pará, 6 (setembro de 1919):136-138.

ROOSEVELT, Anna. "Amazonian Anthropology: Strategy for a New Synthesis" em ROOSEVELT, Anna, ed. Op.cit.:1-29. 
RUSSAN, Ashmore. "Working Rubber estates in the Amazon". Indian Rubber World 27:1(1902).

RUSSEL-WOOD, A. The Portuguese Empire, 1415-1808. Baltimore and London, The Johns Hopkins University Press, 1998.

SAES, Décio. "Classe Média e Políticas de Classe" in Contraponto (Nov. 1977): 2 (Centro de Estudos Noel Nutels)

SAES, Décio. A Formação do Estado Burguês no Brasil (1888-1891). Rio de Janeiro, Paz e Terra, 1985.

SAES, Décio. Classe Média e Política na Primeira República Brasileira (18891930). Petrópolis, Editora Vozes Ltda, 1975.

SALLES, Vicente. “A Cabanagem, os Escravos, os Engenhos," Brasil Açucareiro 36(5)1968:33-38.

SALLES, Vicente. Memorial da Cabanagem: Esboço do Pensamento PolíticoRevolucionário no Grão-Pará (Belém: cejup, 1992.

SALLES, Vicente. O Negro no Pará, sob regime da escravidão. Rio de Janeiro, Fundação Getúlio Vargas/UFPa, 1971.

SANTOS, Roberto. Histórica Econômica da Amazônia, 1800-1920. São Paulo, T.A. Queiroz, 1980.

SCHMINK, Marianne. "Big Business in the Amazon", em Denslow, Julie e Padoch, Christine. People of the Tropical Rain Forest. Berkeley/Los Angeles/ London, University of California Press, 1988.

SCHWARTZ, Stuart. Sugar Plantations in the Formation of Brazilian Society. Cambridge, Cambridge University Press, 1985.

SERRÃO, Emanuel. "Pastagens nativas do trópico úmido brasileiro: Conhecimentos atuais", in Anais do primeiro simpósio do trópico úmido, 12 and 17 de novembro de 1984. Brasília, EMBRAPA, 5(1986): 183-205.

SHAPIN, Steven. "History of Science and Its Sociological Reconstructions." History of Science 20:157-211.

SILVA, Adalberto. "Raizes da Ocupação Recente das Terras do Acre". Belo Horizonte, Cedeplar-UFMG, 1982 (Dissertação de mestrado).

SILVA, L. A Luta pela Amazônia. S. Paulo, Fulgor, 1962.

SILVA, Moacir. "O Desenvolvimento Comercial do Pará no Período da Borracha (1870-1914)”. Niterói, UFF.ICHF, 1978 (Dissertação de mestrado). 
SILVA, Sérgio. Expansão Cafeeira e Origins da Indústria no Brasil. São Paulo, Alfa Ômega, 1981.

SOARES, José. A Borracha. Paris, L. Chauny et \& Quinsac, 1927.

SODRÉ, Nelson. História Militar do Brasil. Rio de Janeiro, Civilização Brasileira, 1968.

SOUZA, E. "A Crise da Indústria de Borracha na Amazônia". Revista da Associação Comercial do Amazonas (Janeiro 1914):58-59.

SPIX, Johann \& Carl F. Martius. Viagem pelo Brasil, 1817-1820. Belo Horizonte, Itatiaia, São Paulo, USP, 1981.

STENBERG, Hilgard. A Àgua e o Homen na Várzea do Careiro. Belém, Museu Paraense Emílio Goeldi, 1998.

THOMAS, Keith. Man and the Natural World. London, Penguin Books Ltd, 1983.

TRECCANI, Girolamo. Violência e Grilagem: Instrumentos de Aquisição da Propriedade da Terra no Pará. Belém, UFPa/ITERPA, 2001.

VIOTTI DA COSTA, Emília. Da Monarquia à República: momentos decisivos. São Paulo, Brasiliense, 1985.

WALLACE, Alfred. Viagens pelo Amazonas e Rio Negro. São Paulo, Cia. Ed. Nacional, 1939, c1853.

WEINSTEIN, Barbara. The Amazon Rubber Boom, 1850-1920. Stanford, Stanford University Press, 1983.

WOODROFFE, Joseph \& Smith, Harold. The Rubber Industry of the Amazon, and How Its Supremacy Can be Maintained. Londres, Bale, Sons and Danielson, 1915.

WRIGHT, Herbert. "Rubber Cultivation (with special reference to parts of the British Empire)". Journal of the Royal Society of Arts 55(1907):614-643. 

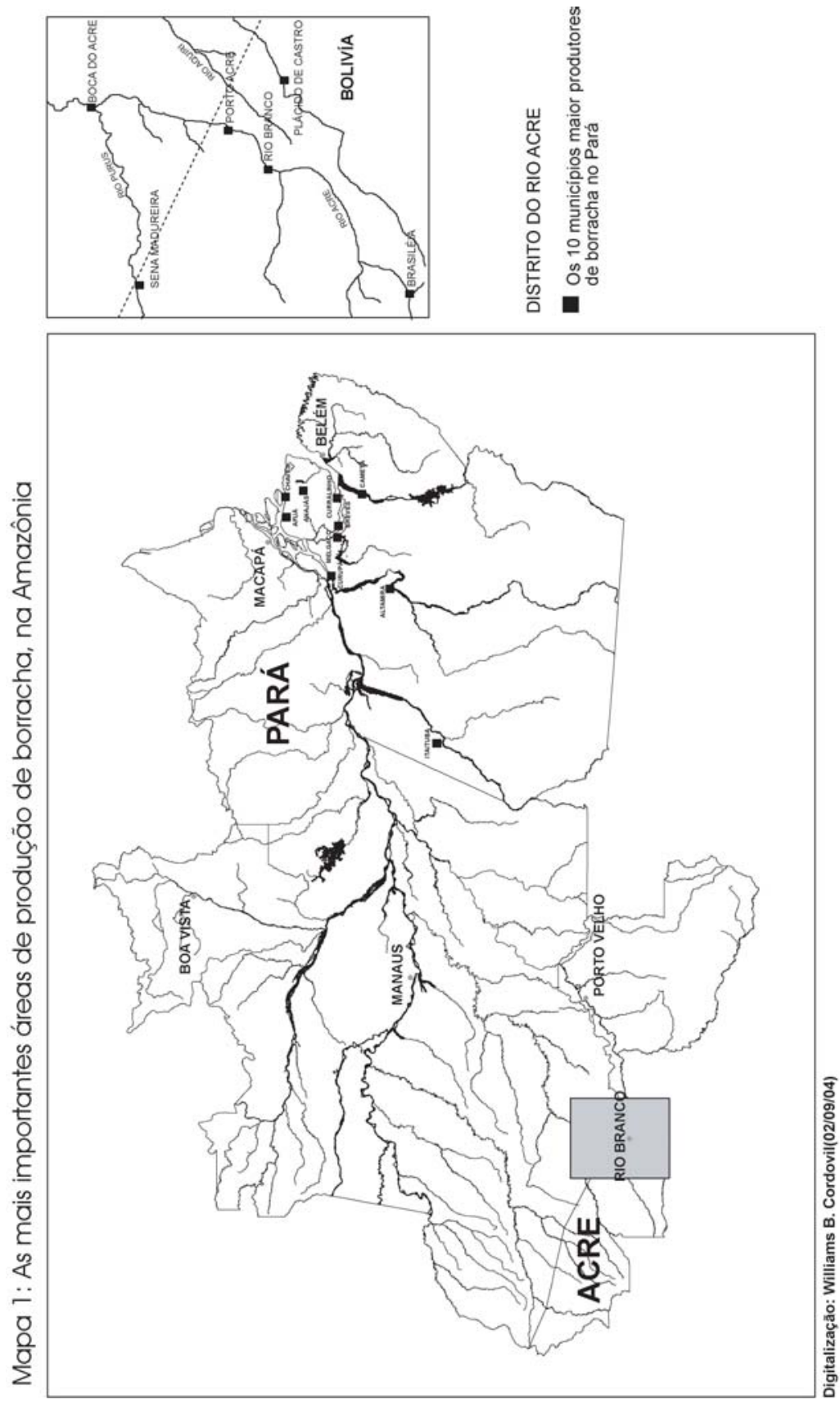


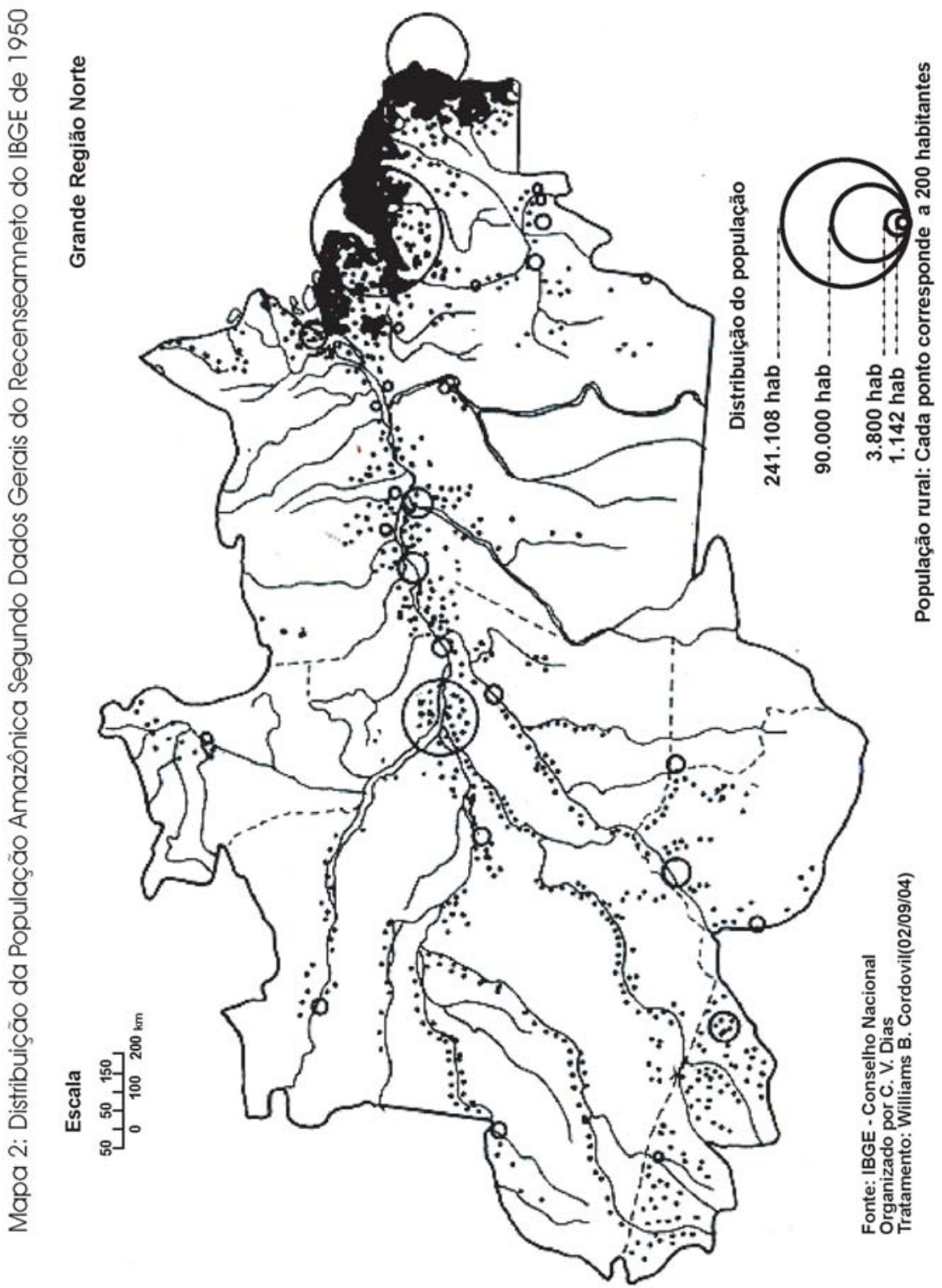

